\title{
ANALISIS JUMLAH PERTUMBUHAN PENDUDUK PEREMPUAN KOTA PONTIANAK MENGGUNAKAN METODE MATRIKS LESLIE
}

\author{
Hasan Mustofa
}

\section{INTISARI}

\begin{abstract}
Matriks Leslie merupakan salah satu metode yang dapat digunakan untuk memprediksi pertumbuhan suatu populasi penduduk. Penelitian ini bertujuan untuk menentukan pertumbuhan populasi penduduk perempuan dikota Pontianak tahun 2019 menggunakan Matriks Leslie. Adapun faktor yang berpengaruh dalam pertumbuhan penduduk adalah tingkat kesuburan dan tingkat ketahanan hidup. Rumus yang digunakan untuk memprediksi jumlah penduduk p tahun berikutnya dengan menggunakan Matriks Leslie adalahn $(t+p)=A^{p} n(t)$ dengan A merupakan Matriks Leslie dann $(t+p)$ adalah vector penduduk berisi prediksi jumlah penduduk pada kelas ke- $(t+p)$ sedangkan $n(t)$ adalah vektor populasi yang berisi jumlah penduduk pada kelas umur ke-t. Hasil prediksi pada jumlah penduduk perempuan kota Pontianak tahun 2019 diperoleh sebanyak 315.218 jiwa, sedangkan jumlah penduduk perempuan pada tahun 2017 berjumlah 314.775 jiwa. Hal ini menunjukkan pertumbuhan penduduk perempuan cenderung meningkat.
\end{abstract}

Kata Kunci: Tingkat kesuburan, ketahanan hidup, prediksi

\section{PENDAHULUAN}

Metode Matriks Leslie merupakan salah satu metode yang dapat digunakan untuk menentukan pertumbuhan populasi serta distribusi usia dalam suatu populasi dari waktu ke waktu. Metode ini hanya digunakan untuk satu jenis kelamin saja dan dalam metode inihanya memprediksijenis kelamin perempuan. Model ini merupakan model yang paling umum dari pertumbuhan penduduk yang digunakan oleh pakar demografi [1].Matriks Leslie dapat diperoleh dari penurunan vektor kolom distribusi usia pada waktu pengamatan, setiap entri pada vektor didefinisikan sebagai banyaknya perempuan dalam kelompok usia ke- $i$ pada waktu ke-t. Pada waktu pengamatan ke- $t$, banyaknya perempuan dalam kelas usia pertama ditentukan dari jumlah anak yang lahir dari setiap kelas usia perempuan diantara waktu ke- $t$ dan $t-1$, sehingga diperoleh entri pada baris pertama matriks yang merupakan kelompok usia subur, sedangkan pada kelas usia selanjutnya ditentukan dari peluang kelangsungan hidup sehingga diperoleh entri pada subdiagonal matriks[2].

Tujuan dari penelitian ini adalah untuk memprediksi jumlah penduduk perempuan kota Pontianak pada tahun 2019 dengan menggunakan Matriks Leslie. Penelitian ini hanya memprediksi jumlah penduduk perempuan Kota Pontianak menggunakan metode Matriks Leslie. Faktor yang digunakan dalam pertumbuhan penduduk adalah tingkat kesuburan, tingkat ketahanan hidup dan rentang umur dari penduduk. Langkah-langkah yang dilakukan untuk memprediksi jumlah penduduk perempuan $p$ tahun berikutnya dengan menggunakan Matriks Leslie adalah membentuk sebuah vector kolom $n(t)$ yang entrinya merupakan jumlah awal penduduk tiap kelas umur. Kedua adalah dicarin $(t+p)$ yang merupakan jumlah penduduk untuk ptahun berikutnya menggunakan rumus $n(t+p)=A^{P} n(t)$ dengan A merupakan matriks Leslie.

\section{MATRIKS LESLIE}

Matriks Leslie merupakan salah satu matriks yang digunakan untuk mengetahui pertumbuhan populasi terpaut usia. Matriks Leslie ditemukan oleh seorang pakar ekologi bernama P. H. Leslie pada tahun 1945. Model ini menjelaskan pertumbuhan betina dari populasi manusia atau hewan. Dalam model ini, yang betina dibagi atas kelompokumur yang kurun waktunya sama [1]. Persamaan umum model populasi MatriksLeslie adalah sebagai berikut [3].

$$
n(t+1)=A n(t)
$$


Tabel 1.Hasil Perhitungan Statistika Deskriptif

\begin{tabular}{cccccc}
\hline Variabel & $\mathbf{N}$ & Minimum & Maksimum & Mean & Std.Deviasi \\
\hline$n^{t}$ & 16 & 4.371 & 32.641 & 19.362 & $9.507,32$ \\
$n^{t-1}$ & 16 & 4.294 & 33.440 & $19.673,44$ & $9.879,28$ \\
$A_{i}$ & 16 & 56 & 8.558 & $1.491,63$ & $2.699,87$ \\
\hline
\end{tabular}

Dimana $n(t)$ merupakan vektor sebaran usia pada waktu $t, n(t+1)$ adalah vektor sebaran usia pada $t+1$ dan $A$ adalah Matriks Leslie. Sehingga bentuk umum persamaan dapat dituliskan sebagai berikut:

$$
\left[\begin{array}{c}
n_{1}(t+1) \\
n_{2}(t+1) \\
n_{3}(t+1) \\
\vdots \\
n_{i-1}(t+1) \\
n_{i}(t+1)
\end{array}\right]=\left[\begin{array}{cccccc}
a_{0} & a_{1} & a_{2} & \cdots & a_{i-1} & a_{i} \\
b_{0} & 0 & 0 & \cdots & 0 & 0 \\
0 & b_{1} & 0 & \cdots & 0 & 0 \\
0 & 0 & b_{2} & \cdots & 0 & 0 \\
\vdots & \vdots & \vdots & \ddots & \vdots & \vdots \\
0 & 0 & 0 & \cdots & b_{1-1} & 0
\end{array}\right] \cdot\left[\begin{array}{c}
n_{1}(t) \\
n_{2}(t) \\
n_{3}(t) \\
\vdots \\
n_{i-1}(t) \\
n_{1}(t)
\end{array}\right]
$$

Untuk mengetahui prediksi jumlah pertumbuhan penduduk hingga $p$ tahun berikutnya dilakukan beberapa pengembangan sehingga diperoleh:

$$
\begin{aligned}
& n(t+1)=A n(t) \\
& n(t+2)=A n(t+1)=A A n(t)=A^{2} n(t) \\
& n(t+3)=A n(t+2)=A A^{2} n(t)=A^{3} n(t) \\
& n(t+4)=A n(t+3)=A A^{3} n(t)=A^{4} n(t) \\
& n(t+5)=A n(t+4)=A A^{4} n(t)=A^{5} n(t) \\
& \cdot \\
& \cdot \\
& \cdot \\
& n(t+p)=A n(t+(p-1))=\dot{A} A^{p-1} n(t)=A^{p} n(t)
\end{aligned}
$$

Model pertumbuhan penduduk untuk $p$ tahun berikutnya adalah:

dimana:

$$
n(t+p)=A^{p} n(t)
$$

$n(t+p) \quad$ : vektor penduduk yang berisi prediksi jumlah penduduk pada kelas saat $t+p$

$\boldsymbol{A}$

$n(t) \quad$ : vektor populasi yang berisi jumlah penduduk pada kelas umur saat $t$.

\section{STUDI KASUS}

\section{Data}

Data yang dianalisis dalam penelitian ini adalah data jumlah penduduk perempuan tahun 2016 yang didefiisikan dengan $\left(n^{t-1}\right)$ sedangkan data jumlah penduduk perempuan tahun 2017 didefinisikan $\left(n^{t}\right)$, dan data tingkat kelahiran anak tahun 2016 dan $2017\left(A_{i}\right)$. Adapaun statistika deskriptif dari data yang digunakan dapat dilihat pada Tabel 1.

Untuk mengetahui prediksi jumlah pertumbuhan penduduk digunakanlah metode Matriks Leslie. Karakteristik Matriks Leslie yang pertama terletak pada elemen Matriks Leslie yang hanya ditentukan dengan dua factor yakni, tingkat kesuburan dan tingkat ketahanan hidup. Kedua, aturan letak elemen Matriks Leslie, pada baris pertama elemen Matriks Leslie berisikan entri-entri dari tingkat kesuburan, dan elemen subdiagonalnya berisikan entri-entri dari tingkat ketahanan hidup, sedangkan elemen yang lain bernilai nol.

Bentuk umum Matriks Leslie sebagai berikut:

$$
A=\left[\begin{array}{cccccc}
a_{0} & a_{1} & a_{2} & \cdots & a_{i-1} & a_{i} \\
b_{0} & 0 & 0 & \cdots & 0 & 0 \\
0 & b_{1} & 0 & \cdots & 0 & 0 \\
0 & 0 & b_{2} & \cdots & 0 & 0 \\
\vdots & \vdots & \vdots & \ddots & \vdots & \vdots \\
0 & 0 & 0 & \cdots & b_{1-1} & 0
\end{array}\right]
$$


Didefinisikan $\left(a_{i}\right)$ tingkat kesuburan perempuan yaitu perbandingan jumlah anak yang lahir dengan jumlah penduduk perempuan pada kelas ke- $i$ tahun ke- $t$, dimana $a_{i} \geq 0$ untuk $i=1,2, \ldots ., n$.

$$
\begin{gathered}
a_{i}=\frac{A_{i}}{n_{i}{ }^{t}}, \quad i=1,2, \ldots, n \\
a_{1}=\frac{A_{1}}{n_{1}{ }^{t}}=\frac{0}{28.944}=0 \\
\cdot \quad \cdot \\
a_{16}=\frac{A_{16}}{n_{16}{ }^{t}}=\frac{0}{4.375}=0
\end{gathered}
$$

Sedangkan, $\left(b_{i}\right)$ tingkat ketahanan hidup yaitu perbandingan jumlah penduduk perempuan pada kelas ke- $i+1$ tahun ke- $t$ dengan jumlah penduduk perempuan pada kelas ke- $i$ tahun ke- $t-1$ [4], dimana $b_{i}>0$ untuk $i=1,2, \ldots, n-1$

$$
\begin{gathered}
b_{i}=\frac{n_{i+1}{ }^{t}}{n_{i}{ }^{t-1}} \quad i=1,2, \ldots, n \\
b_{1}=\frac{n_{2}{ }^{t}}{n_{1}{ }^{t-1}}=\frac{26.036}{28.313}=0,91958 \\
\cdot \quad \cdot \\
b_{15}=\frac{n_{16}{ }^{t}}{n_{15}{ }^{t-1}}=\frac{4.375}{4.371}=1,00092
\end{gathered}
$$

Data populasi perempuan berdasarkan kelas umur diperoleh data tingkat kesuburan $\left(a_{i}\right)$ dan ketahanan hidup $\left(b_{i}\right)$ perempuan di kota Pontianak pada tahun 2017 sebagai berikut:

Tabel2Tingkat KesuburandanKetahanan HidupPerempuan

\begin{tabular}{cccc} 
Nomor & KelasUmur & $\boldsymbol{a}_{\boldsymbol{i}}$ & $\boldsymbol{b}_{\boldsymbol{i}}$ \\
\hline 1 & $0-4$ & 0 & 0,91958 \\
2 & $5-9$ & 0 & 0,99553 \\
3 & $10-14$ & 0 & 1,25086 \\
4 & $15-19$ & 0,0403 & 1,09769 \\
5 & $20-24$ & 0,21358 & 0,86355 \\
6 & $25-29$ & 0,30362 & 0,92886 \\
7 & $30-34$ & 0,13187 & 0,97543 \\
8 & $35-39$ & 0,10572 & 0,87896 \\
9 & $40-44$ & 0,03915 & 0,87397 \\
10 & $45-49$ & 0,00305 & 0,84075 \\
11 & $50-54$ & 0 & 0,82807 \\
12 & $55-59$ & 0 & 0,70096 \\
13 & $60-64$ & 0 & 0,71206 \\
14 & $65-69$ & 0 & 0,68441 \\
15 & $70-74$ & 0 & 1,00092 \\
16 & $75+$ & 0 & \\
\hline
\end{tabular}

Berdasarkan Tabel2 jumlahdata tingkat kesuburan penduduk perempuan pada kelas umur ke-1 untuk rentang umur 0-4 tahun adalah 0, kelas umur ke-2 untuk rentang umur 5-9 tahun adalah 0, kelas umur ke-3 untuk rentang umur 10-14 adalah 0, kelas umur ke-4 untuk rentang umur 15-19 adalah 0,0403 dan seterusnya sampai kelas umur ke-16 untuk rentang umur $75+$ adalah 0 . 
Sedangkan, jumlah tingkat ketahanan hidup penduduk perempuan pada kelas umur ke-1 untuk rentang umur 0-4 tahun adalah 0,91958, kelas umur ke-2 untuk rentang umur 5-9 tahun adalah 0,99553 dan seterusnya sampai kelas umur ke-15 untuk rentang umur 70-74 adalah 1,00092.

\section{Prediksi Jumlah Penduduk Perempuan dengan Matriks Leslie}

Berdasarkan Tabel 2 diperoleh Matriks Leslie sebagai berikut:

$A=\left[\begin{array}{cccccccccccccccc}0 & 0 & 0 & 0,0403 & 0,21358 & 0,30362 & 0,13187 & 0,10572 & 0,03915 & 0,00305 & 0 & 0 & 0 & 0 & 0 & 0 \\ 0,91958 & 0 & 0 & 0 & 0 & 0 & 0 & 0 & 0 & 0 & 0 & 0 & 0 & 0 & 0 & 0 \\ 0 & 0,99553 & 0 & 0 & 0 & 0 & 0 & 0 & 0 & 0 & 0 & 0 & 0 & 0 & 0 & 0 \\ 0 & 0 & 1,25086 & 0 & 0 & 0 & 0 & 0 & 0 & 0 & 0 & 0 & 0 & 0 & 0 & 0 \\ 0 & 0 & 0 & 1,09769 & 0 & 0 & 0 & 0 & 0 & 0 & 0 & 0 & 0 & 0 & 0 & 0 \\ 0 & 0 & 0 & 0 & 0,86355 & 0 & 0 & 0 & 0 & 0 & 0 & 0 & 0 & 0 & 0 & 0 \\ 0 & 0 & 0 & 0 & 0 & 0,92886 & 0 & 0 & 0 & 0 & 0 & 0 & 0 & 0 & 0 & 0 \\ 0 & 0 & 0 & 0 & 0 & 0 & 0,97543 & 0 & 0 & 0 & 0 & 0 & 0 & 0 & 0 & 0 \\ 0 & 0 & 0 & 0 & 0 & 0 & 0 & 0,87896 & 0 & 0 & 0 & 0 & 0 & 0 & 0 & 0 \\ 0 & 0 & 0 & 0 & 0 & 0 & 0 & 0 & 0,87397 & 0 & 0 & 0 & 0 & 0 & 0 & 0 \\ 0 & 0 & 0 & 0 & 0 & 0 & 0 & 0 & 0 & 0,84075 & 0 & 0 & 0 & 0 & 0 & 0 \\ 0 & 0 & 0 & 0 & 0 & 0 & 0 & 0 & 0 & 0 & 0,82807 & 0 & 0 & 0 & 0 & 0 \\ 0 & 0 & 0 & 0 & 0 & 0 & 0 & 0 & 0 & 0 & 0 & 0,70096 & 0 & 0 & 0 & 0 \\ 0 & 0 & 0 & 0 & 0 & 0 & 0 & 0 & 0 & 0 & 0 & 0 & 0,71209 & 0 & 0 & 0 \\ 0 & 0 & 0 & 0 & 0 & 0 & 0 & 0 & 0 & 0 & 0 & 0 & 0 & 0,68441 & 0 \\ 0 & 0 & 0 & 0 & 0 & 0 & 0 & 0 & 0 & 0 & 0 & 0 & 0 & 0 & 1,00092 & 0\end{array}\right]$

Diketah $p=2$ yang berarti dua tahun mendatang dant $=1$ dimanan(1) adalah jumlah perempuan tahun 2017 sebesar 314.775 sebagai jumlah populasi awal. Dengan menggunakan persamaan berikut ini maka :

Sehingga diperoleh

$$
\begin{gathered}
n(t+p)=A^{p} n(t) \\
n(3)=A^{2} n(1)
\end{gathered}
$$

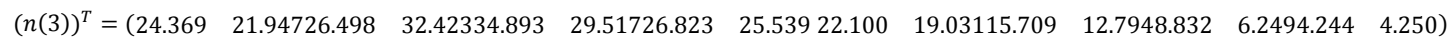

Jadi prediksi total dari jumlah penduduk perempuan pada tahun 2019 kota Pontianak adalah 315.218 jiwa.

\section{PENUTUP}

Berdasarkan hasil dan pembahasan maka diperoleh kesimpulan dari hasil pengaplikasian Matriks Leslie yang menunjukkan bahwa prediksi jumlah penduduk perempuan pada tahun 2019 sebesar 315.218 jiwa. Sedangkan jumlah penduduk perempuan pada tahun 2017 sebesar 314.775. Hal ini menunjukkan bahwa pertumbuhan penduduk perempuan kota Pontianak pada tahun 2017 dalam skala perhitungan 2 tahun meningkat sebesar 1.090 jiwa.

\section{DAFTAR PUSTAKA}

[1]. Anton H dan Rorres C. Aljabar Linear elementer versi aplikasi edisi kedelapan jilid 1. Jakarta: Erlangga; 2002.

[2]. Simanihuruk M dan Hartanto.Karakterisasi Matrik Leslie Ordo Tiga. Jurnal Gradien Volume.2 No.1 Januari2006 : 134-138; 2006.

[3]. ChenLi-Judan Chen Shun-Yu.The influence of profitability on firm value with capital structure as the mediator and firm size and industry as moderators. Investment Management and Financial Innovations journal, Volume 8, Issue 3; 2011.

[4]. Pratama Y, Pribahandono dan Kusumasturi Aplikasi Matriks Leslie Untuk Memprediksi Jumlahdan Laju Pertumbuhan Suatu Populasi. Buletin Ilmiah Math.Stat. Dan terapannya, Volume 02, no.3, hal 163-172.2013

Hasan Mustofa

: Jurusan Matematika Fmipa Untan, Pontianak, hasanmustofa526@gmail.com 